\title{
Knautia arvensis (Caprifoliaceae), a new record for the flora of Turkey
}

\author{
Bilge TUNÇKOL ${ }^{1}$, Necmi AKSOY ${ }^{2}$, Hasan YAŞAYACAK ${ }^{3}$ \\ ${ }^{1}$ Bartın University, Ulus Vocational School, Forestry Department, \\ 74600 Ulus, Bartın, Turkey; bilgetunckol@gmail.com \\ ${ }^{2}$ Düzce University, Faculty of Forestry and DUOF Herbaria Konuralp, \\ 81620 Düzce, Turkey \\ ${ }^{3}$ Küre Mountains National Park Directorate, 74100 Bartın, Turkey
}

Accepted: 7 April 2021

Key words: Dipsacoideae, field scabious, identification key, new floristic record, Northern Turkey.

\begin{abstract}
Knautia arvensis (L.) Coult. (Caprifoliaceae), collected from Küre Mountains National Park (Kastamonu Section), is reported for the first time for the flora of Turkey. A brief description of the plant along with photographs and distribution map is given. Additionally, its taxonomic relationship with other closely allied taxa are examined and discussed. An identification key to the species of genus Knautia in Turkey is provided.
\end{abstract}

\section{Introduction}

Knautia is a genus in the Dipsacoideae subfamily of the Caprifoliaceae with 48 species distributed mostly in western Eurasia and northwestern Africa (Bobrov 1957, Ehrendorfer 1976, Kok Kini 1991). The Flora of Turkey (MATTHEWs 1975) contains 8 Knautia species, while subsequent floristic studies increased the taxon number to 9 in Turkey. Two of these - Knautia byzantina Fritsch and Knautia shepardii Post \& Beauverd - are endemic (MAтt Hews 1975, DAVIS et al. 1988, GöKTÜRK 2012).

Specimens belonging to the genus Knautia were collected during the floristic studies in the Kastamonu province of Turkey. Based on a detailed examination of available specimens, protologue and relevant literature (BOISSIER 1875, BoBRov 1957, EHRENDORFER 1976, KoKKINI 1991, ReCHINGER and LACK 1991), the specimens were identified as Knautia arvensis (L.) Coult. An exhaustive survey of the available literature (MATthews 1975, DAVIS et al. 1988) proved that this species has not been recorded previously within the political boundaries of Turkey. As a result of this, the total number of Knautia species in the flora of Turkey has increased to 10. A detailed description of the species along with photographs, conservation status and relevant notes are provided in this paper. An identification key to the species of genus Knautia in Turkey is provided for easy identification in the field. 


\section{Materials and methods}

Plant samples belonging to the genus Knautia were collected from Kastamonu section of Küre Mountains National Park in 2019. The specimens were identified following the detailed scrutiny of specimens, authentic literature and by comparing with the specimens of this genus in DUOF, GAZI and ISTO herbaria in Turkey in 2019. The specimens were also compared with material in the herbarium of RBGE (Royal Botanical Garden Edinburgh). Photographs were taken in the field by using a Canon 5D DSLR Camera, and morphological observations were made by using an Olympus SZ61 stereo microscope.

\section{Results and discussion}

We give the following description of the Knautia species newly discovered for Turkey. For photographic documentation of plant morphology see Figure 1.

Knautia arvensis (L.) Coult., Mém. Dipsac. 41. 1823; 41. 1823. Basionym: Scabiosa arvensis L., Sp. Pl.: 99. 1753 - Lectotype: Herb. Burser XV (2): 5 (FERRER-GALLEGO 2014).

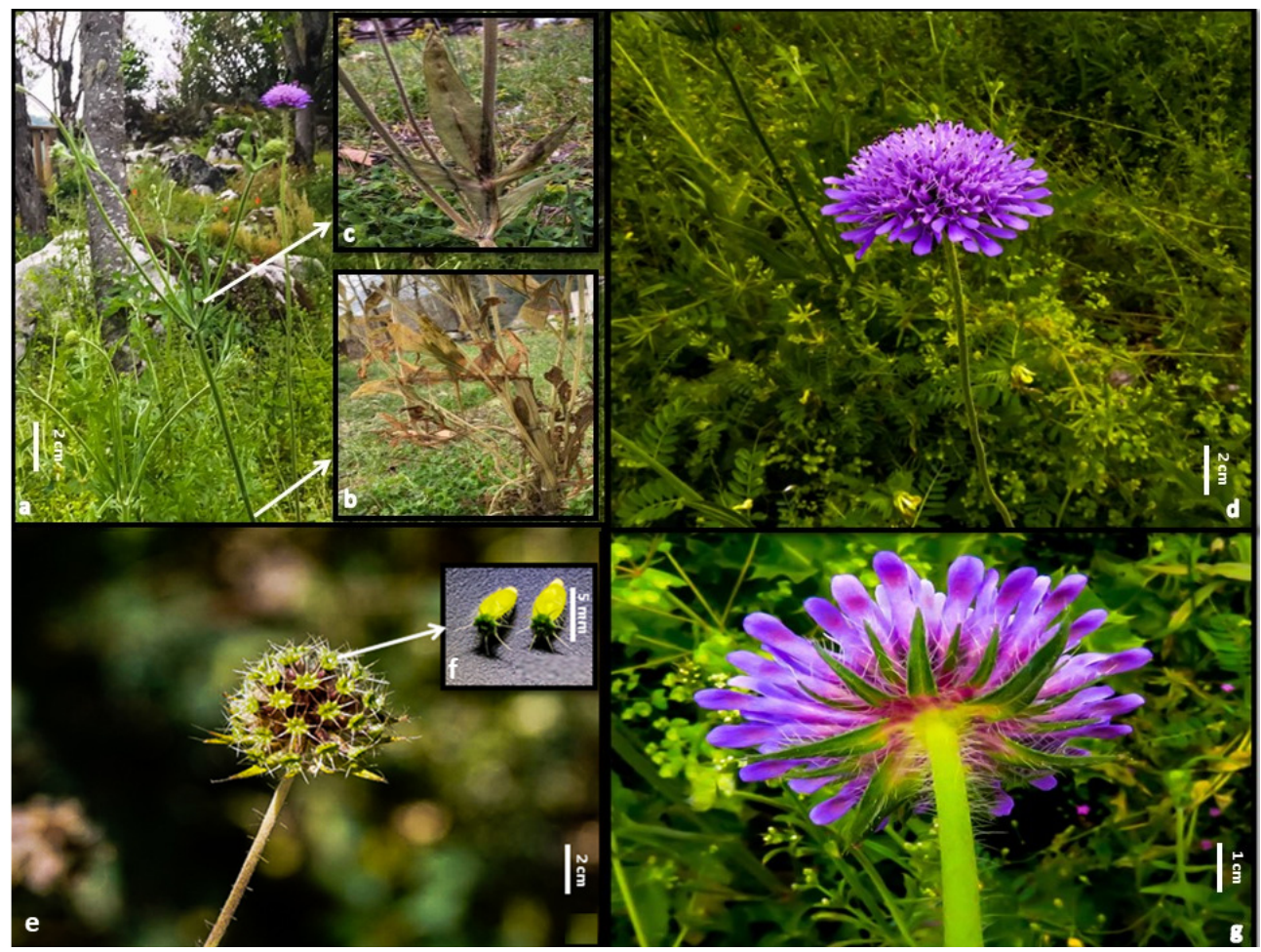

Fig. 1. General appearance of Knautia arvensis (L.) Coult ( $\mathrm{a}=$ plant habit; $\mathrm{b}=$ basal leaves; $\mathrm{c}=$ cauline leaves; $\mathrm{d}=$ inflorescence; $\mathrm{e}=$ capitula; $\mathrm{f}=$ achenes; $\mathrm{g}=$ involucral bracts). 
Description: Perennial; rootstock multicapital, decurrent; stems 80-100(150) $\mathrm{cm}$, erect, sympodial, laxy cespitose, with leaf rosettes. The lower internodes long or short, without purplish spots, more or less hirsute or setose and puberulent; petioles eglandular, leaves usually subhirsute; basal leaves green, undivided or lyrate-pinnate; cauline leaves often confined to lower half of stem, lanceolate to narrowly ovate, usually lyrate-pinnate. Cauline leaves with 3 lateral lobes, ovatelanceolate, subacute, sub-dentate terminal lobe usually much shorter than the divided part. Hermaphrodite capitula $2.5-3 \mathrm{~cm}$ in diameter; female capitula $2 \mathrm{~cm}$ in diameter. Calyx cupuliform, (6-)8(-10)-awned. Involucral bracts 1-veined, ovate, lanceolate, base purple, margins ciliate. Corolla violet or blue, $9-15 \mathrm{~mm}$ long in outer flowers, 6-7 mm long in inner flowers. Achene ovate-oblong, 5-6 mm long, hairy.

Flowering and fruiting: Flowering from April to mid-June, fruiting from July to August.

Ecology and habitat: In Turkey, it grows in meadows and open forest habitats in Küre Mountains at an altitude between 600 to $950 \mathrm{~m}$ above sea level. This taxon was collected at two localities in Kerte Village and in Sümenler Village in Pınarbaşı district. The habitat of this plant is in the core zone of Küre Mountains National Park. As there were only a few individuals encountered in its habitat, it is suggested that this species should be classified as endangered (EN) in Turkey (IUCN 2001). In its locality, the following taxa were abundant: Acer campestre L. subsp. campestre, Carpinus betulus L., Crataegus pentagyna Waldst. \& Kit. ex Willd., Euphorbia stricta L., Fraxinus excelsior L. subsp. excelsior, Filipendula vulgaris Moench, Galium aparine L., Geranium pyrenaicum Burm. f., Iris sintenisii Janka subsp. sintenisii, Onopordum tauricum Willd., Ostrya carpinifolia Scop., Papaver lacerum Popov, Pisum sativum L. subsp. elatius (M. Bieb.) Aschers. \& Graebn. var. elatius Aschers. \& Graebn., Potentilla recta L., Quercus hartwissiana Steven, Silene coronaria (Desr.) Clairv. ex Rchb., Smyrnium perfoliatum L., Sorbus torminalis (L.) Crantz var. torminalis, Stachys thirkei K. Koch, Tanacetum parthenium (L.) Sch. Bip., Tordylium maximum L., Vicia sativa L. subsp. sativa, Vicia pannonica Crantz var. pannonica, Viola kitaibeliana Schult.

Distribution: Europe, Russia, Transcaucasia and now Turkey (Fig. 2).

Specimens examined: Turkey, Kastamonu, Küre Mountains National Park, Pınarbaşı district (B. Tunçkol 4505, DUOF 1946).

Conservation status: It is a newly discovered record for Turkey; the species is rare in the country. Specimens were collected in two localities: in Kerte village ( $\left.41^{\circ} 42^{\prime} 35^{\prime \prime} \mathrm{N}, 33^{\circ} 07^{\prime} 50^{\prime \prime} \mathrm{E}\right)$ and Sümenler village ( $\left.41^{\circ} 42^{\prime} 16^{\prime \prime} \mathrm{N}, 33^{\circ} 02^{\prime} 19^{\prime \prime} \mathrm{E}\right)$ in Pınarbaşı district on 19 May 2019. The habitat of this plant is in the core zone of Küre Mountains National Park. 


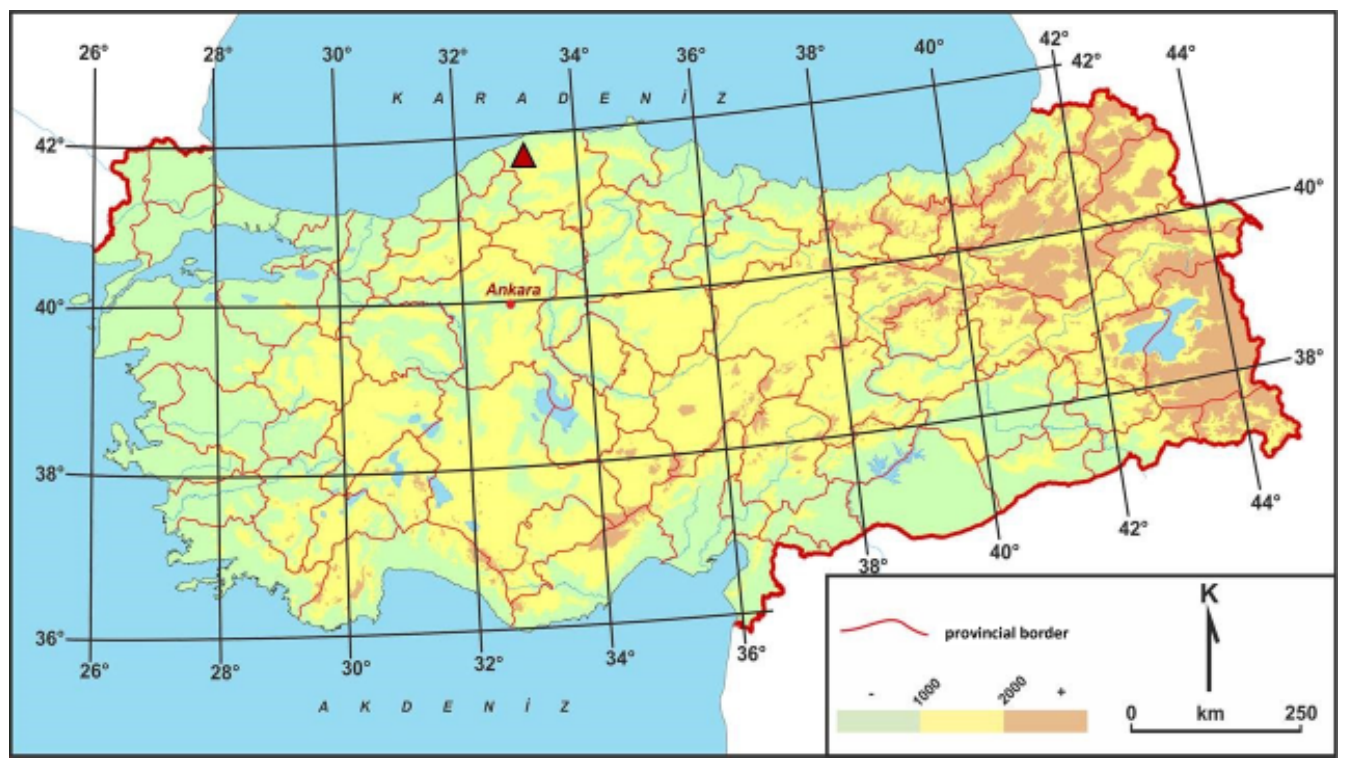

Fig. 2. Occurrence of Knautia arvensis in Turkey. The newly found locality reported in this study is denoted by a triangle.

The comparison of selected morphological characters for the most similar Knautia species in the flora of Turkey is given in Table 1. We propose the following identification key to the species of Knautia occurring in Turkey.

1a Capitula 5-10-flowered; involucral bracts 5-10, erect 2

1b Capitula 10-many-flowered; involucral bracts 10-20, spreading

2a Stem setose hairy; flowers reddish purple; involucral bracts 5-8(-9) 3

Stem glabrous; flowers pale lilac; involucral bracts $8-10$ K. shepardii Post \& Beauverd

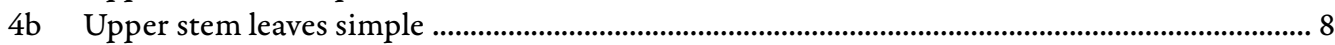

5a Perennials or biennials; flowers violet, blue or red; calyx setae 8 ................................................. 6

5b Annuals; flowers bluish, purplish or pink; calyx setae numerous ................................................. 7

6a Terminal lobes of cauline leaves crenate or serrate; flowers red .............. K. macedonica Griseb.

6b Terminal lobes of cauline leaves subdentate; flowers violet or blue ....... K. arvensis (L.) Coult.

$7 \mathrm{a}$ Involucral bracts acuminate, not prominently nerved; corolla lobes with elliptic petals

K. integrifolia (L.) Bert.

Involucral bracts not acuminate, prominently nerved; outer flowers with lanceolate petals .... K. degenii Borbás ex Formanek

Perennial; lower leaves ovate to elliptic, simple; peduncles pilose, often glandular-hairy

8b Annual; lower leaves linear, sometimes lyrate; peduncles hispid, eglandular 
9a Leaves entire (sometimes lower leaves crenate), up to $4(-6) \mathrm{cm}$ broad; calyx setae 8-10 K. involucrata Sommier \& Levier

9b Leaves crenate or serrate, (4-)5-10 cm broad; calyx setae 10-14 ..... K. montana (M. Bieb.) DC.

Table 1. Comparison of morphological characters of the most similar species of Knautia occurring in Turkey.

\begin{tabular}{|c|c|c|c|c|}
\hline & K. macedonica Griseb. & $\begin{array}{l}\text { K. arvensis (L.) } \\
\text { Coult. }\end{array}$ & $\begin{array}{l}\text { K. degenii Borbás } \\
\text { ex Formanek }\end{array}$ & $\begin{array}{l}\text { K. integrifolia } \\
\text { (L.) Bert. }\end{array}$ \\
\hline Life form & perennial or biennial & $\begin{array}{l}\text { perennial or bien- } \\
\text { nial }\end{array}$ & annual & annual \\
\hline Stems & $\begin{array}{l}\text { up to } 80 \mathrm{~cm} \text { tall, white } \\
\text { tomentose }\end{array}$ & $\begin{array}{l}\text { up to } 150 \mathrm{~cm} \text { tall, } \\
\text { hirsute }\end{array}$ & $\begin{array}{l}\text { up to } 60 \mathrm{~cm} \text { tall, } \\
\text { reflexed setose }\end{array}$ & $\begin{array}{l}\text { up to } 80 \mathrm{~cm} \text { tall, } \\
\text { reflexed setose }\end{array}$ \\
\hline Lower leaves & lanceolate & lanceolate & lanceolate & elliptic \\
\hline Flowers & deep rose or rose-purple & dark violet to lilac & lilac to violet & violet \\
\hline $\begin{array}{l}\text { Involucral } \\
\text { bracts }\end{array}$ & $\begin{array}{l}12-16(-20), \text { ovate-lan- } \\
\text { ceolate, acute at apex, } \\
\text { prominently } 5 \text {-veined }\end{array}$ & $\begin{array}{l}2-16(-20), \text { lan- } \\
\text { ceolate, acute } \\
\text { at apex, promi- } \\
\text { nently } 1 \text {-veined }\end{array}$ & $\begin{array}{l}10-15, \text { narrow } \\
\text { elliptic-lanceo- } \\
\text { late, acute at } \\
\text { apex, promi- } \\
\text { nently veined }\end{array}$ & $\begin{array}{l}10-15(-20), \\
\text { ovate-lanceo- } \\
\text { late, acuminate } \\
\text { at apex, veins } \\
\text { not prominent }\end{array}$ \\
\hline Calyx setae & 8 & 8 & $12-16$ & $12-24$ \\
\hline
\end{tabular}

The specimens collected in Turkey show marked differences from specimens from Europe. The following characteristics are found as important differences: the average height of the plant is $150 \mathrm{~cm}$, peduncles eglandular, bracts are purple at the base, and cauline leaves with 3 lateral lobes. These differences can be attributed to the polymorphic nature of the species. Knautia arvensis usually grows in open forest habitats in the Euro-Siberian floristic region. It is a highly polymorphic EuroSiberian species with a wide distribution ranging from Western Europe throughout Western Asia, with centres of diversity in the Balkans and Southern Alps (FraJM AN et al. 2015). $K$. arvensis typically occupies various semi-ruderal grasslands and has a rather continuous distribution at low and middle altitudes. The two relict species presumably of late Pleistocene/early Holocene origin (previously included in the polymorphic $K$. arvensis) occur spatially isolated in Central Europe (KoLA $\check{R}$ et al. 2015). The new record of $K$. arvensis reported here suggest floristic connection between the Balkans, Southern Alps and northern part of Turkey. Extensive field studies may uncover further occurrences of $K$. arvensis in northern Turkey.

\section{Acknowledgements}

This study was supported by Bartın University (BAP; 2019-Fen-B-005). We thank two anonymous reviewers for very helpful comments. 


\section{References}

Bobrov E. G. 1957: Dipsacaceae. In: SHISH KIN B. K. (ed.) Flora of the USSR, Vol. 24, Akademiya Nauk SSSR, Moscow, pp. 10-91.

Boissier E. 1875: Flora Orientalis: sive, Enumeratio plantarum in oriente a Graecia et Aegypto ad Indiae fines hucusque observatarum, Vol. 3, H. Georg, Geneve and Basel, pp. 126-130.

Davis P. H., Mill R. R., TAN K. 1988: Flora of Turkey and the East Aegean Islands, Vol. 10, Edinburgh University Press, Edinburgh, p. 157.

Göktürk R. S. 2012: Knautia. In: Güner A., Aslan S., Ekim T., Vural M., Babaç T. (eds) A checklist of the flora of Turkey (vascular plants). Nezahat Gökyiğit Botanik Bahçesi ve Flora Araştırmaları Derneği Yayını, İstanbul, pp. 317-318.

Ehrendorfer F. 1976: Knautia. In: Tutin T.G., Heywood V. H, Burges N. A., Valentine D. H., Walters S. M., WebB D. A. (eds) Flora Europaea, Vol. 4, Cambridge University Press, Cambridge, pp. 60-68.

FERRER-GALLEGo P. P. 2014: Lectotypification of Linnaean names in the genus Scabiosa (Dipsacaceae). Taxon 63(6): 1353-1357. https://doi.org/10.12705/636.8

FrajMan B., ReŠEtniK I., Weiss-SchneEweiss H., Ehrendorfer F., SChönSWETter P. 2015: Cytotype diversity and genome size variation in Knautia (Caprifoliaceae, Dipsacoideae). BMC Evolutionary Biology 15: 140. https://doi.org/10.1186/s12862-015-0425-y

IUCN 2001: IUCN Red List Categories and Criteria, Version 3.1. IUCN Species Survival Commission. IUCN, Gland, Switzerland and Cambridge, UK.

Kokkini S. 1991: Knautia L. In: STrid A., TAN K. (eds) Mountain Flora of Greece, Vol. 2, Edinburgh University Press, Edinburgh, pp. 354-358.

Kolář F., KaPlan Z., SUfa J., ŠTECH M. 2015: Populations of Knautia in ecologically distinct refugia on the Hercynian massif belong to two endemic species. Preslia 87: 363-386.

Matthews V. A. 1975: Knautia L. In: Davis P. H. (ed.) Flora of Turkey and the East Aegean Islands, Vol. 4, Edinburgh University Press, Edinburgh, pp. 598-601.

ReChinger K. H., LACK H. W. 1991: Dipsacaceae. In: ReChinger K. H. (ed.) Flora Iranica, Vol. 168, pp. 1-67. 